\title{
Research on Ecological Feminist Literary Criticism
}

\author{
Tingting Zhang
}

Teaching and Research Institute of Foreign Languages, Bohai University, Jinzhou, 121013, China

tingting810905@163.com

Keywords: eco-feminism; literary criticism; ecological criticism; research suggestions

\begin{abstract}
Ecological feminism is the product of the combination of feminism and ecological movement, from the gender Angle of ecological problems, stressed that the two concepts for gender equality and ecological protection organically together. Ecological feminist literary criticism has experienced from ethical culture to the development of the literary criticism, is to the ecological criticism and an optimized combination of feminist literary criticism. In this paper, through the study of the characteristics of ecological feminist literary criticism, the genre and domesticating translation, puts forward China's ecological and feminist literary criticism's research suggests that, for China's ecological and feminist literary criticism theory and method. To advocate to establish a kind of human and nature, man and woman, the harmonious coexistence of the ecological environment.
\end{abstract}

\section{Introduction}

Ecological feminism criticism is the product of the organic combination of feminist criticism and ecological criticism. Feminists advocate overthrowing the rule of the patriarchal, make women end to up status and personality independent road. Feminist literary criticism to subvert the patriarchal culture and eliminate the male-centered culture, is a question of traditional values and literary criticism, is a branch of structuralism criticism after the trend. Ecological criticism mainly studies the relationship between literature and nature, natural literature inheritance of tradition, but also has its own characteristics. Mainly on literature review, promoting reading literary works from the perspective of ecology, strengthen environmental protection consciousness and suffering consciousness, allow a human being. Ecological criticism includes not only the scope of research works showed the relation between man and nature, also include other types of work, efforts to explore the environmental significance. Ecological feminism is the women's liberation movement and the combination of the environmental movement [1-3]. Advocate natural combined with feminist thoughts, is not only a kind of feminist theory, is a kind of ecological theory, at the same time is also a kind of multiple cultural perspectives. Ecological feminist literary criticism theory in the field of literature was born with a "female virtues" and "ecological principle" as the new measure of literary value, and save the nature for mission to liberate women, dual rule discussed in the literature, deepen the criticism of the patriarchy text. Ecological feminism criticism feminist criticism and the product of the organic combination of the ecological criticism. Feminists advocate overthrowing the rule of the patriarchal, make women end up status and personality independent road. Feminist literary criticism to subvert the patriarchal culture and eliminate the male-centered culture, is a question of traditional values and literary criticism, is a branch of structuralism criticism after the trend. Ecological criticism mainly studies the relationship between literature and nature, natural literature inheritance of tradition, but also has its own characteristics. Mainly on literature review, promoting reading literary works from the perspective of ecology, strengthen environmental protection consciousness and suffering consciousness, allow a human being. Ecological criticism includes not only the scope of research works showed the relation between man and nature, also include other types of work, efforts to explore the environmental significance. Ecological feminism is the women's liberation movement and the combination of the environmental movement [1-3]. Advocate natural combined with feminist thoughts, is not only a kind of feminist theory, is a kind of ecological theory, at the same time is also a kind of multiple cultural perspectives. Ecological feminist literary criticism theory in the field of literature was born with a 
"female virtues" and "ecological principle" as the new measure of literary value, and save the nature for mission to liberate women, dual rule discussed in the literature, deepen the criticism of the patriarchy text.

In the face of growing ecological crisis, economic, political and cultural and other fields has made a different reaction. In the field of such as sociology, environmental ethics, deep ecology and ecological feminism emerging disciplines successive, investigate the root cause of environmental degradation and ecological crisis, set up a live view of sustainable development, to establish a harmonious relationship between man and nature provides the concept of ethics and the foundation. Some ecological feminists on environmental issues and gender issues from the perspective of literature research, ecological feminism to infiltrate literary [4]. Ecological and feminist literary criticism is a combination of feminist criticism and ecological criticism of two different areas, using dual Angle of view to re-examine the classic literary works, excavation has not been important writers and works, certainly including the ecological consciousness and female consciousness, discrimination and women discrimination against species, questioning and deconstruct the binary opposition idea, criticism of anthropocentrism and patriarchy culture center, showed a new thinking and reading perspective, get the favour of literary critics. Ecological feminist literary criticism is also used to interpret the traditional classic literature tradition traditional men and men, compare the differences in male and female writer writing, presents a whole new meaning to readers. From a practical point of view, ecological literary criticism theory to guide people to pay attention to the current ecological crisis, gender discrimination and the inner link, guide people from the dual Angle of view of environment and gender literature research, called on people to take care of women and nature, eventually make the natural environment, harmonious and coordinated development of men and women.

\section{Features on Ecological Feminist Literary Criticism}

Within the ecology feminine literary criticism theory field of vision, the women's life and the natural environment combining site basically has the following several aspects: first, compares with the earth mother in the traditional culture, the nature of the earth function and women pregnant strikingly similar function, women with their own flesh and blood children, the earth cycle to produce the products; Second, the nature and women in the patriarchal society suffers the idea base of the domination and oppression. Value dualism male centered in western culture, establish the relation between man and nature, men and women; Third, the source of nature and women oppressed. In the center of the patriarchal culture of the dominant society, nature and women have been banished to the edge position, become the victim of patriarchal society. Ecological feminism challenge to the traditional philosophy, as a new philosophy change the way people see the world, through the criticism of traditional patriarchy view of the world, to make their own value system literature writer cognitive social, evaluation and new standard the meaning of life [5, 6]. Ecological literary criticism has the following features:

(1) Reveal natural relations with women in the literature. Combine women and nature, and are closely linked, comfort each other, depend on each other. Because in the patriarchal society, women were the "natural" at the same time can also be "feminine". Women are often depicted as natural symbol of elegant and beautiful, delicate and charming be about to drip rose, simple but elegant of Oriental cherry calmly and frame clank of the plum blossom. Women's tragic fate is often similar to natural, all experience the respect and warm, suffering from the war, and realize the industrial civilization.

(2) Combine anthropocentrism and male-dominated system criticism. Men become the master of nature, gradually make women materialization, this is patriarchy value orientation in the field of literary criticism. Ecological feminists paint a beautiful picture for the human society, everyone has a dual temperament, at the same time with masculinity and femininity. Ecological feminist criticism by literary form to act as spokesperson for justice and freedom, between man and nature, man and woman together to study.

(3) Has a unique quality of literature and writing skills. Ecological feminism literature, rich 
change, show a gentle female literature characteristics. Ecological feminism literature also have their own writing skills, in the perspective of biological, let the natural self narration. Female literature writers are not consciously like this way of writing. They called for humans should learn in a new Angle, namely the Angle of ecological feminist literary criticism, the point of view of the whole ecosystem problem, nature and human.

\section{Genre on Ecological Feminist Literary Criticism}

Scholars to join different academic background to the study of ecological feminism, bring their own unique academic perspective, for the liberation of nature and women ways and understanding is different, thus formed the different genres of ecological feminism. Ecological feminists due to their respective reference theory approach, the focus and dual emancipation of women and nature the understanding of the basic way is different, and ecological feminism brings out the genre of plural pattern, including cultural ecological feminism, social ecological feminism and ecological feminism philosophy [7].

(1) The cultural ecological feminism: emphasis on the spiritual and cultural root of oppression suffered by women and nature, the change of the cultural spirit as the basic way of double liberation of women and nature. Specifically, is to build a new female culture, one is to build good care ethics, demonstrates the moral basis of the harmonious relationship between man and nature; Second, religious revival of the ancient goddess of nature, inspire feelings of respecting the nature.

(2) Spiritual ecological feminism: women essentially contact with nature, not only points out that the level of binary view provides a foundation for men dominate nature and women, and even promote the ancient goddess worship. Such as Starhawk further unique experience through a woman's body, let faith based upon ground to the women's movement to provide ideas and strength, such as internality, relevance and sympathetic way of life.

(3) Social ecological feminism: double oppression suffered by women and nature of the social political and economic causes, the social, political, and the change of the economic system as the basic way to realize double liberation of women and nature. In the patriarchy economic development model, the natural oppression of women and strengthen each other. By referencing a lot of facts that argument women in daily life experience to environmental degradation effect on life, from the deep analysis of the ecological crisis and the status of women.

(4) Green ecological feminism: claim to love nature, protect animals, love the earth and species of equality. Active in social activities, against war and violence, anti pollution and resource abuse, carnivorous and cruelty to animals, the maintenance of world peace and gender equality, advocate natural without borders. Standing on the perspective of ecological creation, through empathic artistic technique, with women or various plants and animals to the eye and the heart feeling and tell the world.

(5) The ecological feminism philosophy: the concept of level analysis of women and nature under the sway of double inner link, think that people's behavior controlled by the concept, control and control of nature of women is decided by the idea of a common structure, to liberate women and nature, the most important is to break the concept of "structure". Philosophy of ecological feminist manifesto eradication patriarchy world outlook and values.

\section{Research Realm on Ecological Feminist Literary Criticism}

As a subversion of the patriarchy-centered philosophy and the social cultural ideological trend, ecological feminism to spread in the west, and affects the many subjects such as politics, sociology, environment and ethics. When ecological feminism extended to research women literature and literary language and literature, which specializes in environment, marks a new ecological feminism into the field of literary creation and literary criticism. Since the $1990 \mathrm{~s}$, ecological feminist literary criticism has been developing rapidly in the educational world, broadening the research observes.

(1) Ecological text search and interpretation to women. Due to close to women and nature, a better understanding of the talents of natural value, more know to cherish and respect nature. 
Therefore, women can create a more friendly feeling and exquisite literature, raise the environmental consciousness of mankind. Therefore, ecological feminist literary criticism is an important task, is to find and excavate traditional literature ecological feminist literature of annihilation, and carries on the value of the review, to get a new meaning.

(2) The male text reflective comments. The implication of ecological consciousness of male writers works as the research object, praised male writers works exude ecological feminism consciousness, including one's own nature, interpersonal relationship and the nature harmonious coexistence, etc. Male writers as the spokesman of the "rational", often in the works of nature with the female image distortion. For this kind of male text, critics claim with a critical eye parsing, eliminating patriarchy ideas in work.

(3) The revaluation of the value of literary classics. Literature concept is not only refers to the development of new work, more is to use the new criticism field of vision, found the possibility of text reading, the existing works. Ecological feminism literary criticism itself is a kind of ecological creation, based on the ecological feminist reading creation perspective for the reconstruction of the classics. To critical reading of literature classics, construct an ecological and feminist criticism way of thinking and way of reading.

(4) The construction of ecological feminist literary criticism theory. To ecological feminist philosophy, ethics and its corresponding rational thinking and logic knowledge as the foundation, to explore the shortcomings of traditional criticism theory, continuously exceed the initial theory, the problem of more text, and fields as the research category, to discover and extend in the interpretation of specific texts, expand new field of vision, find new problems, and to form new ideas, construct a diversity of literary criticism.

\section{Research Proposal on Ecological Feminist Literary Criticism in China}

China's ecological and feminist literary criticism until the new century began as an independent study category, but so far has yet to build up the systematic model of criticism. As in the domestic academic field frontier and full of vitality criticism theory, ecological feminism is a new kind of literary criticism to upsurge. At the same time, there are still some deficiencies in development: superficial criticism theory research, the lack of depth and systematic; Confined to a few text reading classic, lack of breadth and reality; More to stay in a small and a single field of literary criticism, not comprehensive docking with the literary creation, thus influencing and guiding literary creation; As diversified literary criticism concept, ecological feminist literary criticism of the broadness, openness, crossed and the advantages of the interactive has not fully displayed. Aiming at these deficiencies, this paper presents the research suggests the following [8-11] :

(1) Research on ecological feminist criticism theory itself to innovate, do not do western theory followed. Too much will depend on western theories makes people lose their own unique personality, therefore, should have the courage to walk in the front of the western academia, brave put forward my own method of criticism. With enough courage and insight to self innovation of theory itself, can make the development of their own have new breakthrough. Specific conditions in China, if can the criticism theory with China's social reality, the Chinese literary tradition combine well, by adopting methods such as comparison of Chinese and western has more realistic meaning in society.

(2) Used as a whole and contact study of thinking. The Chinese traditional history culture soil has accepted the thought of ecological feminism, and the foreign concept is also the Chinese way of thinking. As ecological feminist thoughts spread in the global scope, on the one hand to connect with Chinese history and culture, on the other hand comb to be carried out in accordance with the Chinese way of thinking. From the source to solve environmental problems, we must get rid of the thinking mode of dualism in the patriarchal society, will be "against nature, the use of natural and modified natural" thinking, into the "harmony between man and nature, respect nature, love nature" thinking mode.

(3) Introduce the literary criticism to literature conscious creation and cultural life. Through ecological feminist criticism, arouse the people to the natural environment of love and respect and 
appreciation of women, creating ecological feminist consciousness of literature creation, makes the criticism and creative practice is more closely linked, in real sense, makes the natural and women take part in the social development, equally to man and nature, man and a woman of great harmony, to achieve the ultimate concern of literary criticism. If the development which progresses by leaps and bounds in this aspect, China's ecological and feminist literary criticism will walk in the forefront of the western countries and the world.

(4) Excavate in traditional literature outstanding works, restore ecological feminist literary classics. Most scholars lack from the history of literature in the treasure house to develop ability of literary classics and confined to the classics have been determined and writer. In fact, there are a lot of literary classics is waiting for discovery. From the perspective of ecological feminism works, can feel the nature and the resonance of the female. In interpreting works of women writers at the same time, to discover and interpret some male writers works. Only in this way can literary criticism has distinguishing feature alone, to keep the vigor and vitality for long. Eventually led to the human and the nature, the harmonious development between man and woman, arouse people to respect for nature and women, making equal nature and women involved in the social development.

(5) Construct the diversity of literary criticism. Ecological feminist criticism is criticism and feminist criticism, ecological criticism is a cross, ecology and literary criticism is based on the ecological philosophy and ecological ethics of a kind of criticism, feminist criticism is based on the theory of feminism criticism. Draw lessons from the western ecological science, ecological philosophy, ecological ethics and corresponding rational thinking and logic knowledge, construct the concept of diversification of literary criticism is an important goal of ecological feminist literary criticism. In the emphasis on integrity, harmony, interactivity and diversity in the process of cultural theory, ecological feminism literature and criticism will play an important role and unique theory.

\section{Conclusion}

Ecological feminism is the combination of ecological and feminism, is beyond the ethics of environment and development. With the extensive development of ecological feminism, have been deeply involved in the environment, ethics, politics and philosophy, and other fields, and its far-reaching influence. When touch, ecological feminism and linguistics provides a new perspective for literary creation and literary criticism, and for the formation of ecological feminist literary criticism thought laid a foundation. Through this article research, to understand its thought origin, development process and criticism practice. Stilettos to the female and the nature in the role, status, the root causes of common place, and how the patriarchy society value dualism, hierarchical thinking and logic implementation rule on the domination and oppression of both [12]. Through the concrete application of the criticism method, set up a kind of human and nature, man and woman healthy and harmonious coexistence of the ecological environment.

\section{Acknowledgement}

This work is supported by social science fund project of Liaoning province (L15CWW001): Western Feminist Literary Criticism and Its Influence on Chinese Female Writing.

\section{References}

[1] Y. Y. Hua, "The rise and development of eco feminist literary criticism in the United States," Frontiers of Literary Theory, vol. 11, no. 1, pp. 77-102, 2014.

[2] J. H. Chen, "A Call from Females and Nature: A Review on the Literary Criticism from the Eco-feminism Approach," Journal of Hubei University (Philosophy and Social Science), vol. 34, no. 3, pp. 69-72, 2007. 
[3] R. Xu, "Spring is no longer silent women no longer aphasia: Analysis of the theory of eco feminist literary criticism," Journal of Social Science of Jiamusi University, vol. 33, no. 2, pp. 120-122, 2015.

[4] F. J. Chen, L. F. Zhao, "From literature to reality: the contemporary interpretation of eco feminist literary criticism," Chinese Social Sciences Weekly, 2015-3-13.

[5] X. G. Zhu, "Construction of Female Consciousnes," Journal of Jiamusi Education Institute, vol. 30, no. 12, pp. 98-99, 2013.

[6] Gao Juan, "I look at the eco feminist literary criticism," Chinese writers network: http://www.chinawriter.com.cn/bk/2011-09-26/56426.html, 2015-12-1.

[7] Y. J. Wang, "On the Genres of the Western Ecofeminist Literary Criticism," Journal of Central South University (Social Science), vol. 18, no. 4, pp. 190-195, 2012.

[8] Y. Q. Fu, C. J. Li, "Eco feminist literary criticism and Its Current Studies in China," Journal of Southwest University of Science and Technology (Philosophy and Social Science Edition), vol. 26, no. 3, pp. 82-87, 2009.

[9] X. Q. Duan, "The Call From Women and and Nature: The Theory Strategy of Eco-feminist Literary Criticism and it's Development China," Master's degree of Liaoning University, 2011.

[10] Y. K. Wang, "The path choice of contemporary China from the perspective of eco feminist literary criticism," Master's degree of Hainan University, 2012.

[11] M. L. Chen, "A Discussion of Ecofeminist Lite Criticism," Qilu Journal, vol. 76, no. 6, pp. 108-111, 2006.

[12] X. Liu, "Female and Nature: Study on The Eco-feminist Literary Criticism," Master's degree of Huazhong Normal University, 2014. 